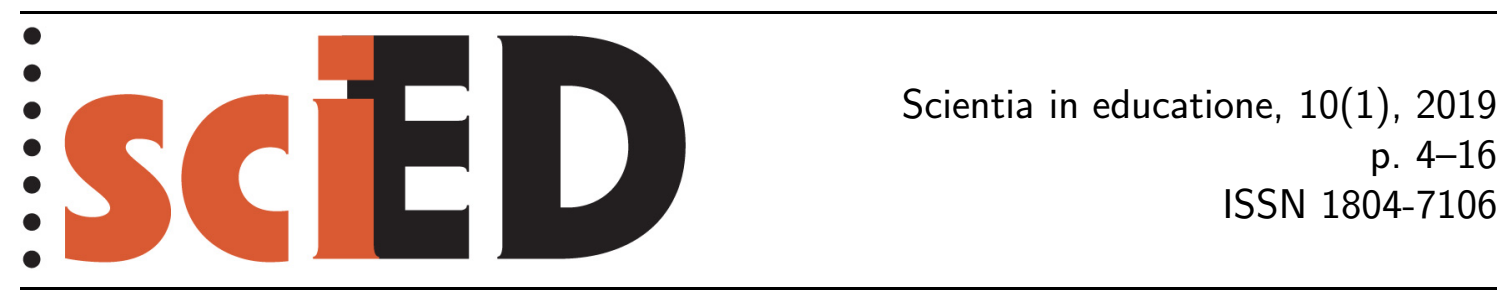

\title{
Proč a jak vyučovat dějiny vědy?
}

\author{
Jana Poupová
}

\begin{abstract}
Abstrakt
Studie upozorňuje na přínos, který může mít začlenění dějin vědy do školní výuky. Sleduje historii výuky dějin vědy od prvních náznaků z Anglie 2. poloviny 19. století přes dobu jejího rozkvětu v poválečných letech až po její proniknutí do kurikulárních dokumentů řady evropských zemí na sklonku 20. století. Uvádí také hlavní mezníky ve výuce dějin vědy v Česku a shrnuje argumenty, kterými se obhajovalo zavádění výuky dějin vědy (např́klad lepší poznání povahy vědy nebo zlidštění odtažitého světa vědy). Na př́kladu dějin biologie hodnotí vyzkoušené metody jejich výuky (například využívání případových studií, životopisů či původních vědeckých textů). Blíže posuzuje výhody a nevýhody konstruktivistického a instrumentálního způsobu výuky dějin biologie a navádí učitele, jak ve výuce využít silné stránky obou přístupů.
\end{abstract}

Klíčová slova: dějiny vědy, povaha vědy, konstruktivistická a instrumentální výuka.

\section{How (and Why) to Teach History of Science?}

\begin{abstract}
The study draws attention to the benefits of teaching history of science (HOS). It deals with the history of HOS education from its beginnings in England in the second half of the 19th century and its expansion during the post-war period till the end of the 20th century when HOS was taken into account in many European curriculum documents. The article enumerates the most important events connected with HOS education in the Czech Republic and summarizes arguments in favour of teaching HOS (e.g. better understanding of nature of science or its humanizing). It evaluates the teaching methods used in the past (e.g. reading and discussing case studies, biographies or original scientific papers). The article provides a detailed description of the advantages and disadvantages of the constructivist and instrumental way of teaching history of biology and encourages teachers to make use of the strong points of both approaches.
\end{abstract}

Key words: history of science, nature of science, constructivist and instrumental teaching. 
V poslední čtvrtině 20. století zažívala výuka přírodních věd v západní Evropě i v USA krizi, která se viditelně projevila zhoršením studentů v mezinárodních srovnávacích testech a poklesem zájmu o studium přírodních věd (McComas, 2014a). Vyvstala proto potřeba najít příčiny této krize a přijmout opatření k jejímu překonání. V této situaci byla položena zásadní otázka: Jaký má mít výuka věd (ve smyslu science, tj. přírodních věd) smysl?

Podle mínění řady odborníků je více než vlastní obsah výuky důležité přiblížení vědeckého pohledu na svět (Lederman, 1992). Výuka vědě (learning of science), at už se jedná o biologii, fyziku nebo chemii, by proto měla být doplněna výukou o vědě (learning about science), ř́ká Matthews (2011). Výuka o vědě by měla ukázat, jak vědecké poznání vzniká, jak se jeho výsledky ověřují, jakou podobu mají vědecké argumenty a co vůbec vědci v práci dělají (McComas, 2014b).

Podle mínění mnoha odborníků se s principy vědeckého př́istupu ke světu jde seznámit jednak přimým provozováním vědy, jednak studiem dějin vědy (Matthews, 2011). Nadále se budeme zabývat druhou možností, která se v průběhu 20. století uplatnila ve větším rozsahu.

V tomto textu rozumíme pod souslovím dějiny vědy dějiny př́rodních věd. Ačkoli dějiny přírodních věd bývají věcně (i institucionálně) propojené s dějinami techniky, kterými se zde nezabýváme. Pro uvedení do problematiky nejprve pojednáváme o výrazných počinech spojených s výukou dějin vědy obecně, tj. bez ohledu na to, zda souvisely s výukou biologie, fyziky, chemie nebo medicíny. S ohledem na výraznou aktivitu Jednoty českých matematiků a fyziků uvádíme i výrazné milníky spojené s výukou dějin matematiky. Kvo̊li rozdílnostem mezi jednotlivými přírodovědnými obory se následující didakticky zaměřená pasáž vztahuje pouze $\mathrm{k}$ výuce dějin biologie.

Argumentů pro výuku věd v jejich historickém kontextu bylo uvedeno mnoho dějiny ukazují vědecké bádání jako proces, jehož výsledek není nikdy definitivní (Horner \& Rubba, 1978), a v němž mohou soupeřit i koexistovat různé pohledy na tentýž problém (Rasmussen, 2007). Brání tak dogmatickému přístupu k soudobému vědění a ukazují vědu jako jeden z mnoha relevantních přístupů, jak se dívat na svět (Matthews, 2011). Mezi další argumenty, proč se ve výuce dějinám vědy věnovat, patří přesvědčení, že probouzejí zájem o přírodní vědy u humanitně zaměřených studentů (Folta, 1998a; Potůček, 1998), zpřístupňují učivo (Hellberg \& Rychtera, 2003), překonávají specializaci jednotlivých oborů, vytvářejí vazby mezi nimi (Jílek \& Mach, 2002) a také ucelený pohled na vědu a její vztah ke společnosti (Hellberg \& Rychtera, 2003; Gruber, 2002).

Dějiny vědy pochopitelně nejsou jediným oborem, který se zabývá vztahem vědy, techniky a společnosti. Této problematice se věnuje filosofie a metodologie vědy, která se snaží reflektovat tendence ve vývoji vědy, a vytváří tak rámec pro interpretaci historických vědeckých faktů. Filosofie a metodologie vědy se přitom opírá právě o př́klady z dějin vědy (Fajkus, 1998), souvislost mezi oběma disciplínami je proto velmi úzká.

Předkládaný text má povahu deskriptivního výzkumu. Jeho cílem bylo zachytit vývoj výuky dějin vědy v Česku (její počátky a význačné počiny) a dát jej do kontextu s děním v Západním světě. Dalším cílem bylo shrnout historicky vyzkoušené způsoby, jak dějiny vědy vyučovat, a doporučit pro dějiny biologie ucelený způsob jejich výuky. Výzkumné otázky byly formulovány takto: Jaké hlavní události se udály v oblasti výuky dějin vědy v českém prostoru v posledních 100 letech? Na jaké obtíže výuka dějin vědy narážela? Koresponduje český vývoj výuky dějin vědy s vývojem v Západním (německy a anglicky mluvícím) světě? Jaké metody byly 
v průběhu posledních 100 let doporučovány $\mathrm{k}$ výuce dějin vědy? Jaký př́istup se hodí pro výuku dějin biologie?

Studie vychází z původních článků zachycujících výzkumy výuky dějin vědy a její historii. V českém prostoru představoval zásadní zdroj informací časopis Dějiny věd a techniky (DVT), v současné době jediné české periodikum zaměřené na dějiny vědy, a Rozpravy Národního technického muzea (NTM). Jako hlavní zdroj informací k situaci v zahraničí (především v Anglii a USA, které mají s výukou dějin vědy nejdelší zkušenost) posloužily články a sborníky International History, Philosophy and Science Teaching Group ${ }^{1}$, mezinárodního sdružení, které vzniklo roku 1987 a vytyčilo si za cíl vylepšit výuku přírodních věd a matematiky s pomocí dějin, filosofie a sociologie vědy. Dále byl v značné míře využit časopis Science $\&$ Education ${ }^{2}$, vydávaný IHPST pro osvětu širší učitelské veřejnosti.

\section{DĚJINY VĚDY A JEJICH VÝUKA V ČESKÝCH ZEMÍCH}

Jednou z prvních osobností, která se zajímala o filosofické a historické pozadí přírodních věd v českém prostoru, byl E. Rádl (1873-1942). Rádl v letech 1905 a 1909 publikoval stěžejní práci z dějin biologie Geschichte der biologischen Theorien. Ve 20. letech dal také na Přrirodovědecké fakultě UK popud ke vzniku semináře zaměřeného právě na metodologii a dějiny př́rodních a exaktních věd.

Jednou z prvních aktivit zaměřených na dějiny vědy v nově vzniklém Československu bylo vytváření soupisu technických památek hodných ochrany a sběr životopisů význačných československých vědců. Tyto činnosti probíhaly pod záštitou Masarykovy akademie práce. V roce 1928 vzniklo z podnětu historika matematiky Q. Vettera Volné sdružení přátel dějin věd exaktních, přírodních, lékařských a technických, předchůdce nynější Společnosti pro dějiny věd a techniky (SDVT). Za první republiky, konkrétně v roce 1921, začala na brněnské veterinární škole výuka dějin veterinární medicíny (Šindelář, 2001). V roce 1924 byl na nynější 1. lékařské fakultě UK založen samostatný ústav věnovaný dějinám lékařství (Strouhal, 1998). Doplníme-li, že se čtvrtý mezinárodní kongres věnovaný dějinám vědy v roce 1937 konal přímo v Praze (první kongres byl v Paříži v roce 1929), je zřejmé, že tehdejší Čskoslovensko za světovým vývojem nikterak nezaostávalo (Folta, 1998b). Počátky snah o větší zohlednění výuky dějin vědy ve školách nicméně začaly až v 80 . letech 20. století. První akcí tohoto typu byla Letní škola dějin matematiky uspořádaná v roce 1980 (tehdy ještě pod názvem Světonázorové problémy matematiky). V průběhu 80. let byly také pod patronací SDVT a NTM zavedeny pravidelné semináře pro učitele a zájemce o dějiny vědy. $Z$ těchto seminářů vzešly v 80 . a 90 . letech svazky Práce z dějin přírodních věd, které se dají využít jako pomocný text při výuce světových dějin vědy a techniky až do 20. století (Folta, 2004).

V dnešní době mívají přírodovědné obory na vysokých školách výuku svých dějin omezenou na pár úvodních poznámek k oboru (Folta, 1996). Velká pozornost není dějinám vědy věnována ani v rámci vysokoškolské výuky historie (Hyna, 2001). K dějinám vědy se studenti obvykle dostanou až v rámci postgraduálního studia, kdy se jim dodatečně věnují bud' historikové - bez dostatečné znalosti př́rodních věd, nebo př́rodovědci - bez znalosti historických metod (Folta, 1998a; Folta, 1996).

Přes výše uvedené však některé přírodovědné obory stále věnují výuce svých dějin značný prostor. Jako př́iklad můžeme uvést již zmiňovanou medicínu (Strouhal,

\footnotetext{
${ }^{1}$ Dostupné z https://www.ihpst.org

${ }^{2}$ Dostupné z https://link.springer.com/journal/11191
} 
1998) a veterinární medicínu (Šindelář, 2001). Na prvorepublikovou tradici výuky filosofie a dějin vědy na Př́rodovědecké fakultě UK navázala po roce 1990 Katedra filosofie a dějin přírodních věd, obnovená z popudu Z. Neubauera ${ }^{3}$.

Hlavní obtíže středoškolských učitelů ve vztahu $\mathrm{k}$ výuce dějin vědy shodně formulují Rozhoň (2002) a Jílek a Mach (2002). Jsou jimi jednak nedostatek vhodného učebního materiálu, potíže s výběrem učiva (malá časová dotace vyžadující stručnost) a nepřipravenost učitelů na toto téma (nedostatečné znalosti historie u učitelů př́rodních věd a technických oborů, resp. nedostatek odborných znalostí u učitelů dějepisu). Gruber (2002) vidí potíž i v malém zájmu středoškoláků o toto téma (obzvlášt jde-li o volitelný předmět) a ve shodě s Karpenkem (1997) i v jejich nedostatečných znalostech obecné historie. Tyto obtíže bývají důvodem nezájmu středoškolských učitelů o výuku dějin vědy.

Jako pozitivní krok proto můžeme hodnotit skutečnost, že se před pěti lety na trhu se středoškolskými učebnicemi objevila řada doplňků k učebnici dějepisu ( $\mathrm{z}$ nakladatelství Scientia) s názvem Stručné dějiny oborů. Ačkoli se tyto příručky snaží zachytit české i světové dění v oboru v celé jeho historii v rozsahu několika desítek stran, jde o cenný počin. Jak totiž dokládá Folta (1998a), středoškolské učebnice dějepisu věnují historickým vědeckým znalostem větší pozornost pouze v antice. Čím více se blížíme $\mathrm{k}$ dnešku, tím je pozornost věnovaná dobové vědě menší, a tím více přibývá nepřesných či vyloženě chybných informací.

\section{DĚJINY VĚDY A JEJICH VÝUKA NA ZÁPADĚ}

Explicitně formulovaná myšlenka, že by se ve školách měly učit nejen výsledky vědeckého poznání, ale také dějiny vědy, zazněla prvně na setkání Britské společnosti pro vědecký pokrok v Glasgow roku 1855 (Jenkins, 2014). Mezi první propagátory přírodovědeckého vzdělání opírajícího se o dějiny vědy patřil anglický učitel F. W. Westaway (1864-1946). Westaway doporučoval učitelům předčítat výňatky původních vědeckých děl a vyprávět žákům životní příběhy velkých přírodovědců, které v nich mohou vzbudit touhu následovat je (Brock \& Jenkins, 2014).

Vzrůst zájmu o výuku dějin vědy spadá v Evropě do druhé dekády 20. století a je dáván do souvislosti s první světovou válkou. Velká válka ukázala vědecké výdobytky v jejich ničivé podobě, a vědě tím pošramotila pověst (Jenkins, 2014). Přrirodovědci proto cítili potřebu vědu zlidštit a zohlednit $\mathrm{v}$ ní také morální hodnoty. A právě $\mathrm{k}$ tomu měly sloužit dějiny vědy, které se $\mathrm{v}$ této době etablují jako samostatná disciplína. Mezi propagátory dějin vědy patřili například sběratel historických vědeckých přístrojů R. Gunther (1869-1940) nebo matematik G. Sarton (1884-1956), který stál u vzniku časopisu Isis (prvně vydaném roku 1913 v Belgii) a v dějinách viděl obranu před roztř́ištěností vědy do dílčích disciplín (Holton, 2003). Historicky zaměřený přístup $\mathrm{k}$ výuce přírodních věd prosazoval $\mathrm{v}$ této době také znalec dějin alchymie E. J. Holmyard (1891-1959). Ten kladl důraz na poznání ekonomických, sociálních a dalších faktorů, které zasahují do vývoje vědy, a byl přesvědčen, že znalost dobového kontextu pomáhá porozumět tehdejším názorům (Jenkins, 2014). Ačkoli byla historicky pojatá výuka teoreticky oceňována, v praxi se neuchytila kvůli nedostatečným znalostem učitelů (Heilbron, 1999; Jenkins, 2014).

Další výrazný mezník související s výukou dějin vědy přinesla 2 . světová válka. Historický přistup $\mathrm{k}$ výuce prrírodních věd prosazoval chemik a dlouholetý ředitel

${ }^{3}$ Dostupné z https://www.natur.cuni.cz/biologie/filosofie/o-katedre 
Harvardovy univerzity J. B. Conant (1893-1978). Jeho cílem se stalo vzdělat občany tak, aby pochopili „strategii a taktiku vědy“ (Heilbron, 1999: s. 10). Klíčovou myšlenku, že kvalitní výuka vědy se musí opírat o její dějiny, představil v knize On understanding science: An historical approach (1947) následujícími slovy: „Jsem přesvědčen, že laik vědě nejlépe porozumí studiem několika málo poměrně jednoduchých případů z dějin." (Conant, 1947: s. 1) Pro výukový kurz, který by se tohoto přistupu držel, sepsal Conant sedm případových studií. Tyto studie nepředkládaly systematický pohled určité disciplíny na dané téma, nýbrž napříč různými obory ukazovaly důležité aspekty vědeckého bádání. Měly velký úspěch, který byl podle mínění některých autorů (např. Heilbron, 1999) nezanedbatelnou měrou podmíněn pedagogickými kvalitami jeho tvůrce.

Mezi pozitivně přijímané projekty z poválečné doby patřil také historicky pojatý kurz fyziky Harvard Project Physics (Wang \& Marsh, 2002) a kurz dějin vědy History of Science Cases. Autor tohoto kurzu L. E. Klopfer ověřoval, jak je historicky pojatá výuka účinná v prostředí středních škol. Z jeho výzkumů vyplynulo, že žáci vyučovaní historickým přístupem na tom nejsou po odborné stránce o nic lépe než kontrolní skupina, ale že lépe rozumí povaze vědy a více oceňují tvořivost dřívějších vědců (Klopfer \& Cooley, 1963).

Za větší prosazení dějin vědy v běžné výuce bojoval v 50. a 60. letech v USA také biolog J. J. Schwab (1909-1988). Schwab upozorňoval, že předkládání hotových poznatků vyvolává v žácích neodpovídající obrázek vědy jako souboru stabilních pravd (DeBoer, 2014; Wieder, 2006). Jako protiopatření doporučoval zohledňovat ve výuce příběhy odehrávající se během vědeckého poznávání a pod vlivem Great Books Foundation doporučoval studovat vybrané dobové výzkumné články, které reprezentovaly různé názory vědců na tentýž problém. ${ }^{4}$

Další vlna zájmu o výuku dějin vědy se v Západním světě objevila v 80. letech v souvislosti s poptávkou po výuce, která by vychovala vědecky gramotné osoby v duchu hesla science for all (Metz, 2014; Wang \& Marsh, 2002). Vyústěním těchto snah bylo založení již zmiňované skupiny IHPST a také americký projekt 2061 (AAAS, 2017). V 90. letech se doporučení seznamovat žáky s povahou vědy pomocí studia jejích dějin poprvé objevila v kurikulárních dokumentech některých zemí (například v americkém Science for all Americans vydaném roku 1990). Šlo však o velmi vágní formulace a v praxi se tato doporučení více neuplatnila (McComas, 2014b).

Také evropské země se od 90. let potýkají s klesající přrírodovědnou gramotností žáků a klesajícím zájmem o studium přírodních věd, což dokládá projekt ROSE (Sjøberg \& Schreiner, 2010). Dokumenty EU nicméně hledají východisko především $\mathrm{v}$ problémové výuce a $\mathrm{v}$ badatelsky orientovaném vyučování. A třebaže i v nich najdeme apel, aby si výuka přírodních věd všímala sociálního a kulturního kontextu (Dibattista \& Morgese, 2014), členské státy EU se k této radě staví různě dějiny vědy jako součást výuky přírodních věd doporučuje v závislosti na stupni školy třetina až polovina národních kurikulárních dokumentů. Česko mezi nimi není (Poupová, 2018).

Soudobé evropské aktivity zaměřené na výuku dějin vědy obvykle vycházejí z iniciativy jednotlivých společností pro dějiny vědy (př́kladem takto aktivní společnosti je francouzská Patrimoine, Histoire des Sciences et des Techniques z Brestu) či jednotlivých univerzit. Jejich činnost spočívá obvykle ve tvorbě případových studií, elektronických knihoven s primárními zdroji, ve vytváření a ověřování učebních aktivit pro různé stupně škol, provozování webových stránek popularizujících dějiny

\footnotetext{
${ }^{4}$ Dostupné z https://www.greatbooks.org/about/history
} 
vědy, organizování konferencí, méně často pak ve vytváření multimédií s historicko-vědeckou tematikou. Pro př́klad uved’me alespoň partnerství univerzit v Athénách, Pavii, Oldenburgu, na Kypru a v Soluni nebo činnost univerzity v Yorku (Dibattista \& Morgese, 2014). Univerzita v Yorku stojí za projektem Perspectives on Science, který ostatní evropské počiny převyšuje počtem zapojených studentů. Propojuje př́padové studie z dějin vědy a práci studentů na vlastním výzkumném projektu.

Institucionálně je výuka dějin vědy dobře zajištěná v Německu, kde působí téměř 50 univerzitních pracovišt věnujících se výzkumu v oblasti dějin vědy i jejich výuce. (Na rozdíl od Česka je na řadě z nich možné dějiny př́rodních věd absolvovat i jako hlavní magisterské studium, např́iklad na Universität Hamburg nebo na Ludwig-Maximilians-Universität München. Kompletní seznam kateder a ústavů, které se v německy mluvícím prostoru věnují výuce dějin vědy, jsou $\mathrm{k}$ dispozici na webových stránkách ${ }^{5}$ ).

\section{PříNOS A NEVÝHODY DOBOVÝCH ZPŮSOBŮ VÝUKY DĚJIN VĚDY}

Jak naznačil pohled do historie, výuka dějin vědy často spočívala ve čtení původních vědeckých textů spojeném s následnou diskusí. Tento prrístup plynule přecházel do rozboru případových studií, které se opíraly o výňatky historických článků. Další častou cestou bylo studium životopisů významných vědců, zpočátku výhradně v knižní podobě, později i v divadelním nebo filmovém zpracování.

Výčet dalších možností, jak dějiny vědy vyučovat, shrnuje McComas (2014a: s. $28-42)$ :

Méně obvyklé bylo hraní rolí - at už v podobě divadelní scénky zachycující bud' vybranou událost, nebo celý život daného učence, případně jeho simulovanou přednášku s následnou diskusí. Nepř́lišs využívanou možností bylo předvádění historických pokusů.

McComas (2014a) konstatuje, že nebylo dosud prokázáno, jak jsou jednotlivé způsoby výuky dějin vědy efektivní.

Využití uvedených přístupů $\mathrm{k}$ výuce dějin vědy však není zcela bez problémů. Rozbor původních vědeckých textů vyžaduje vysokou míru čtenářské gramotnosti. Žáci musí dostatečně ovládat terminologii, což může být v prostředí střední školy problém. Porozumění textu navíc ztěžuje skutečnost, že vědecké články bývají v angličtině či jiném cizím jazyce. Jak podotýká Barth (1999), středoškoláci se při práci v cizím jazyce většinou necítí dobře, práce s původními texty je pro ně náročná. Takto vedená výuka sice některé žáky osloví, ale jiné odradí. Další problém může spočívat v nedostupnosti těchto textů a jejich překladů pro učitele. V českém prostředí čítanka tohoto typu chybí. Původní výzkumné články biologického rázu vhodné pro využití ve výuce shromáždili ve své anglicky psané knize Baumel a Berger (1973). Jejich zkušenost ukázala, že je texty původních článků potřeba poněkud upravit zkrátit a zjednodušit. (Každý článek doplnili o úvod přibližující život autora a jeho dobu a o otázky, které žáky navádí k uvědomění si určitého aspektu vědy.) Další anglicky psané zdroje využitelné pro historicky zaměřenou výuku biologie na střední škole najde čtenář v publikaci Eichmana (1996).

\footnotetext{
${ }^{5}$ Dostupné z https://www.hs.uni-hamburg.de/DE/GNT/research/wiss-hist-inst.php
} 
Při práci s textem nemůže učitel spoléhat na učebnice, spíše se musí opřít o popularizující knihy - učebnice totiž v současné podobě neposkytují adekvátní obrázek historie vědy, navíc se této problematice věnují jen okrajově (Hájková, 2017; Leite, 2002; McComas, 2014a). Již zmiňovaný doplněk české učebnice dějepisu Stručné dějiny oborů pojednává pouze o dvou oblastech dotýkajících se středoškolské biologie, a to konkrétně o ekologii (ve spojení s chemií) a medicíně (ve spojení se sociální činností).

Využivání životopisů slavných vědců není žáky jednoznačně přijímáno, podle Eichmana (1996) mají pozitivní dopad drobné životopisné poznámky, které žákům ukáží slavného vědce jako „normálního“ člověka. Podle Bartha (1999) životopisy některé žáky zaujmou, jiné ale nudí. Obdobně nejednoznačně působí podle zkušenosti jiných pedagogů hraní rolí (Wieder, 2006).

Na předvádění historických pokusů si někteří autoři (například Cavicchi, 2008) cení hlavně emočního rozměru. Při práci na nich totiž žáci zažívají jak pocit zmatenosti při obtížích s interpretací dobového textu, který experiment zachycuje, tak očekávání při jeho přípravě, případně zklamání, nevyjde-li podle jejich představ. Navíc podle Cavicchiho (2008) provádění historických pokusů ukazuje, jak jsou vědecká fakta konstruována s pomocí zařízení sestrojených právě pro tento účel. Obnovuje se tím blízký vztah mezi pokusem, použitým materiálem a pozorovaným jevem, což bývá při zpětném líčení dobové vědy často oddělováno. $\mathrm{V}$ praxi však tento způsob výuky naráží na nedostatek zdrojů, o něž by se učitel při jejich přípravě mohl opřít. Jednou z mála publikací do výuky zabývajících se historickými pokusy je anglicky psané kompendium Walkera (1993), to však zahrnuje pokusy z nejrůznějších prrírodovědných předmětů, biologii samotné není věnováno tolik prostoru.

\section{KONSTRUKTIVISTICKÝ A INSTRUMENTÁLNí PŘíSTUP K HISTORICKY POJATÉ VÝUCE}

Z anglofonního prostředí, které se výuce dějin vědy tradičně nejvíce věnovalo, vzešly $\mathrm{v}$ posledních dvaceti letech dva ucelené přístupy $\mathrm{k}$ jejich výuce, které jsou využitelné ve výuce biologie. První, navržený Monkem a Osbornem v roce 1997, začíná sdílením žákovských prekoncepcí o vědě, které posléze žáci s pomocí učitele reflektují. Označuje se proto za konstruktivistický. Druhý př́stup představili v roce 2009 Rudge a Howe jako instrumentální - žáci si principy fungování vědy mají uvědomit při co nejvěrnějším napodobení vědecké práce.

Podle konstruktivistického př́stupu by se výuka v rámci jedné až dvou vyučovacích hodin měla držet následujícího postupu (Monk \& Osborne, 1997) V první fázi je žákům představen zvolený problém. Následně se shromažd’ují žákovské nápady, jak by se tento problém dal řešit. Tato fáze má žákům ukázat mnohost interpretací a poučit je, že vědci fakta spís konstruují, než objevují. Další část výuky je historicky zaměřená - učitel žáky seznámí s ranými představami o daném jevu, názorovými rozepřemi a přiblíží dobový socioekonomický kontext. Se žáky učitel diskutuje o zjištěních, která by mohla dobové názory podpořit, a tuto pasáž zakončí chronologickým přehledem událostí souvisejících s tématem. Takto pojatý historický exkurz by měl být krátký, např́klad 10 minut, a žáky by měl přivést k zamyšlení, proč si lidé mysleli právě to, co si mysleli. Jde o „vyprávění historických příběhů a poučení z nich“ (Monk \& Osborne, 1997: s. 418). Poté žáci navrhují způsob, jak rozhodnout, k jaké verzi vysvětlení problému se přikloní. Využívá se při tom žákovská tvořivost. Může 
jít např́klad o návrh jednoduchého experimentu, jehož realizace není s ohledem na čas nezbytně nutná. Jde o metodologicky zaměřenou fázi, při níž žáci hledají odpověd’ na otázku: Jak se to dá zjistit? Výuka končí tím, že učitel představí soudobý pohled na danou problematiku.

Při instrumentálně laděné výuce mají žáci uvažovat tak, jako uvažovali vědci v minulosti (Rudge \& Howe, 2009). Porozumění problému si vytvářejí výhradně $\mathrm{s}$ pomocí informací, které měli doboví vědci $\mathrm{k}$ dispozici, tj. bez znalosti, $\mathrm{k}$ jakému závěru dospěl pozdější vývoj. Skupinám žáků je vždy položena nějaká otázka, na kterou hledají s pomocí dat, která dostanou k dispozici, odpověd'. Následně si svá vysvětlení komentují, zdůvodňují své pozice a hodnotí argumenty, přičemž učitel jim v žádném okamžiku neříká „správnou“ odpověd’. Autoři tohoto přístupu uvádějí konkrétní ukázku věnovanou výzkumu krve, naplánovanou na osm 90minutových lekcí. Mezi jednotlivé lekce zařazují oddíly věnované povaze vědy. Žáci při nich reflektují, jak se mění jejich interpretace údajů a potažmo jejich teorie.

\section{PorovnÁní KONSTRUKTIVISTICKÉHO}

\section{A INSTRUMENTÁLNÍHO ZPŮSOBU VÝUKY DĚJIN VĚDY}

V následujícím oddíle se budeme věnovat rozdílům, resp. podobnostem obou přístupů, jejich výhodám a nevýhodám.

Jak konstruktivistický, tak instrumentální přístup k historicky pojaté výuce mají společné následující rysy:

1. Snaží se žáky přimět, aby navrhli vlastní vysvětlení určitého jevu, odůvodnili ho a zvážili nejrůznějšś závěry, které z něj plynou. (Instrumentální způsob oproti konstruktivistickému přísněji vymezuje, o co se žákovská vysvětlení mohou opírat.)

2. Oba přístupy vytvářejí prostor pro reflexi vědecké metodologie.

3. Ani jeden z přístupů nehovoří o hodnotě dějin vědy jako takových. Historii oba používají jako nástroj výuky o vědě.

Výhodou konstruktivistického přístupu je skutečnost, že pro učitele není z didaktického hlediska obtížné takto výuku pojmout. K jednotlivým fázím výuky může učitel prřřadit běžné vyučovací metody - nastolení tématu zajistí např́íklad problémová otázka, po níž následuje brainstorming nápadů na její řešení. Historickou pasáž přibližující řešení problému v minulosti pokryje vyprávění nebo práce s textem. K testování potenciálních řešení problému poslouží badatelsky zaměřená skupinová práce. Výuku je možné uzavř́it výkladem učitele shrnujícím soudobý pohled na věc. Výhodou konstruktivistického modelu je i časová nenáročnost, která nekomplikuje jeho využití v běžné výuce.

Problém může spočívat spíše v nedostatečných historických znalostech učitele, resp. v nedostatku patřičně zaměřených učebních materiálo̊ - není-li učitel s dějinami biologie obeznámen, může pro něj být obtížné vybrat pro výuku vhodný historický příběh. Takový příběh by se měl vztahovat k zásadní otázce, jíž je třeba se ve škole věnovat, měl by být poučný, tj. poskytovat žákům reálný obrázek o chodu vědy, a poutavý zároveň. $V$ neposlední řadě by měl žákům umožňovat vymyslet, případně vyzkoušet, ověřující pokus.

Autorům instrumentálního přístupu nicméně na konstruktivistické výuce vadily jiné aspekty. Seznámení s dějinami pokládali za př́liš krátké, upozorňovali, že soudobý pohled na problém není s tím historickým řádně provázán. Konstruktivistický 
přístup podle nich dějiny degradoval tím, že je využíval jen jako zdroj alternativních vysvětlení problému, a žáky vedl ke srovnávání jejich vlastních nápadi̊ s historickými vysvětleními, která však vznikala v úplně jiném kontextu (Rudge \& Howe, 2009). S těmito výhradami nelze než souhlasit.

Instrumentální přístup je $\mathrm{z}$ tohoto hlediska $\mathrm{k}$ minulosti spravedlivější, snaží se s pomocí dobových dat vést úvahy žáků ve stopách dřívějších vědců. Nicméně ani o něm nemůžeme říci, že je historii zcela věrný - vědci v určité době měli $\mathrm{k}$ dispozici nejrůznější údaje, přičemž pro vyřešení problému museli vybrat pouze relevantní data a nenechat se zmást ostatními. Instrumentální způsob však žákům postupně předkládá jen údaje skutečně potřebné. $V$ tomto ohledu se jeho autoři zpronevěřují proklamované zásadě dívat se na problém striktně očima tehdejší doby. Data do výuky vybírají s vědomím toho, co se osvědčilo. Je jasné, že se výuka opírá o zjednodušené situace, nicméně zatímco konstruktivistický přístup zjednodušenost nepopírá, dikce autorů instrumentálního přístupu působí dojmem, že si tohoto zjednodušení nejsou vědomi.

Další potíž instrumentálního přístupu spatřujeme v požadavku, aby se žáci oprostili od soudobého pohledu a pokusili se dívat na problém očima jiné doby. Jde to vůbec chtít po žácích střední školy, aby se vžili do myšlenkového ovzduší určité doby? Považujeme to za nepřiměřené, pochybujeme, že by dokázali uhlídat, aby ke svým nápadům nepoužili nějakou historicky mladší znalost.

Je také otázka, kam úvahy žáků dojdou, když je učitel nijak nesměřuje k dnešnímu pohledu? Očekávat, že zrekapitulují minulost tak, jak se stala, je pošetilé. Rudge a Howe (2009) konstruktivistickému př́istupu oprávněně vyčítají, že zakončení výuky soudobou interpretací problému budí dojem, že jde o definitivní tečku za vývojem poznání (o dále již neměnnou pravdu). Přes toto nebezpečí si myslíme, že není vhodné soudobý výklad problému zcela ignorovat. Shodneme-li se, že znalost historie přináší lepší porozumění současnosti, není štastné, když výuka uvázne v minulosti a nedostane se $\mathrm{k}$ dnešku. Nejen znalost historického vývoje, ale také znalost dnešního stavu vědeckého myšlení je potřebná pro pochopení soudobého pohledu na svět.

Kromě výše uvedených obtíží s sebou instrumentální přistup nese i ty ryze praktické. Je časově náročný a předpokládá, že si učitel opatř̌i dobové vědecké údaje. Jeho realizace může být z těchto důvodů obtížnější.

Shrneme-li dosud řečené, je zřejmé, že ani jeden z obou př́stupů k výuce dějin biologie není ideální. Hlavní výhodou konstruktivistického př́istupu je jasná struktura, které se učitel při výuce může držet, výhodou instrumentálního př́ístupu je větší cit pro historii a historická přesnost. Věříme, že oba př́stupy může učitel ve výuce biologie zkombinovat tak, aby zužitkoval uvedené výhody - může vyjít z konstruktivistického sledu fází, nastolit otázku a dát průchod neusměrňovaným žákovským nápadům. Následně by však měl přibližzit dobové možnosti a společně se žáky eliminovat historicky nemožné nápady. Pak by mohl žáky konfrontovat s údaji dostupnými v dané době a jejich postupným dávkováním je vést $\mathrm{k}$ interpretaci problému. Výuku by učitel mohl zakončit nastolením soudobého pohledu na problém, př̀i němž by ale nesměl zamlčet jevy, které dnes uznávaná teorie neumí dobře vysvětlit nebo na jejichž výklad nepanuje jednotný názor. Tím by u žáků předešel pocitu, že věda již dosáhla kýžené absolutní pravdy. Tento přístup pochopitelně neodstraňuje problém s potenciální nedostupností potřebných učebních materiálů, resp. nedostatkem historických znalostí učitele. 


\section{ZÁVĚR}

Popsaná historie dokládá, že doporučení vyučovat dějiny vědy se na Západě objevuje již na samém počátku prosazování přírodních věd ve výuce. Dějiny vědy byly opakovaně využívány jako nástroj, který má mladé generaci přiblížit podstatu vědecké práce. Většího zájmu se dějiny vědy dočkaly v období první světové války, kdy si od nich intelektuálové slibovali zlidštění vědy v očích veřejnosti, a po druhé světové válce, kdy byl zdůrazňován jejich potenciál srozumitelně přibližit svět vědy laikům. Jejich zohlednění ve vzdělávacích dokumentech je nicméně záležitost posledních třiceti let. V souladu s vývojem na Západě zaznamenáváme také v českých zemích zájem o dějiny vědy na počátku 20. století. Další výraznější vlna však přišla až v 80. letech, požadavek na výuku dějin vědy do českých vzdělávacích dokumentů dodnes nepronikl.

Dějiny vědy ve své školní historii opakovaně narážely na velkou potíž, kterou byla nedostatečná obeznámenost učitelů s touto problematikou. Úspěch s tímto přístupem proto sklízeli spíš výjimeční pedagogové, kteří byli zároveň znalci dějin vědy.

$\mathrm{V}$ minulosti byly vyzkoušeny různé zpo̊soby výuky dějin vědy, nejčastěji šlo o čtení původních vědeckých textů, životopisů a o případové studie. V posledních dvaceti letech byly navrženy dva ucelené přístupy $\mathrm{k}$ výuce dějin vědy, které jsou využitelné i pro výuku biologie. Výhodou konstruktivistického přístupu je jednodušší realizace, instrumentální přístup je zase věrnější historickému pohledu. Věříme, že oba přístupy může učitel biologie ve výuce propojit, a těžit tak z obou výhod.

\section{PODĚKOVÁNí}

Tato publikace byla podpořena programem Univerzitní výzkumná centra UK č. UNCE/HUM/024.

\section{LITERATURA}

AAAS. (2017). About project 2061.

Dostupné z https://www.aaas.org/program/project2061/about

Barth, M. (1999). Dějin vědy na střední škole: zkušenosti z mé třídy a úvahy o jejich zařazení do vzdělávání učitelů. Dějiny věd a techniky, 32(1), 37-48.

Baumel, H. B. \& Berger, J. J. (1973). Biology: Its people and its papers. Washington, DC: National Science Teachers Association.

Dostupné z https://files.eric.ed.gov/fulltext/ED089954.pdf

Brock, W. H. \& Jenkins, E. W. (2014). Frederick W. Westaway and science education: an endless quest. In M. R. Matthews (Ed.), International handbook of research in history, philosophy and science teaching (2359-2382). Dordrecht: Springer.

Cavicchi, E. M. (2008). Historical experiments in students' hands: Unfragmenting science through action and history. Science \& Education, 17, 717-749.

Dostupné z https://doi.org/10.1007/s11191-006-9005-2

Conant, J. B. (1947). On understanding science: An historical approach. New Haven, CT: Yale University Press.

DeBoer, G. E. (2014). Joseph J. Schwab: His work and his legacy. In M. R. Matthews (Ed.), International handbook of research in history, philosophy and science teaching (2433-2458). Dordrecht: Springer. 
Dibattista, L. \& Morgese, F. (2014). Incoporation of HPS/NOS content in school and teacher education programmes in Europe. In M. R. Matthews (Ed.), International handbook of research in history, philosophy and science teaching (2083-2117). Dordrecht: Springer.

Eichman, P. (1996). Using history to teach biology. The American Biology Teacher, 58(4), 200-204. Dostupné z https://www.jstor.org/stable/4450124?seq=1\&cid=pdfreference\#references_tab_contents

Fajkus, B. (1998). Význam filosofie a metodologie vědy pro studium dějin vědy a techniky. In J. Folta (Ed.), Dějiny vědy a techniky 5. 15. a 16. seminár̆ pro vyučujicí dějinám věd a techniky. Rozpravy NTM 157 (16-22). Praha: NTM.

Folta, J. (1996). Dějiny vědy a techniky. Výuka na českých a slovenských vysokých školách. Rozpravy NTM 140. Praha: NTM.

Folta, J. (1998a). Výuka dějinám věd a techniky. In J. Folta, Dějiny vědy a techniky 5. 15. a 16. seminář pro vyučující dějinám věd a techniky. Rozpravy NTM 157 (69-74). Praha: NTM.

Folta, J. (1998b). 70 let organizování historiků vědy a techniky. In J. Folta, Dějiny vědy a techniky 5. 15. a 16. seminář pro vyučujici dějinám věd a techniky. Rozpravy NTM 157 (5-6). Praha: NTM.

Folta, J. (2004). Desetiletí vytváření výzkumného oddělení pro dějiny techniky a exaktních věd Národního technického muzea (1993-2003). In J. Folta (Ed.), Dějiny vědy a techniky 12. 21. seminár̆ pro vyučující dějinám věd a techniky. Rozpravy NTM 189 (5-6). Praha: NTM.

Gruber, J. (2002). Některé aspekty výuky dějin techniky na střední odborné škole. In J. Folta (Ed.), Dějiny vědy a techniky 9. 19. seminář pro vyučujici dějinám věd a techniky. Rozpravy NTM 175 (59-62). Praha: NTM.

Hájková, J. (2017). Dějiny přírodních věd: Jejich místo ve škole a v učebnicích biologie. Scientia in educatione, 8(2), 1-13.

Dostupné z https://ojs.cuni.cz/scied/article/view/758/465

Heilbron, J. L. (1999). Ponaučení z výuky dějinám věd. Dějiny věd a techniky, 32(1), $5-18$.

Hellberg, J. \& Rychtera, J. (2003). Místo historie chemie v učebních plánech pregraduální učitelské př́ípravy s ohledem na její profesionalizační funkci. In J. Folta (Ed.), Dějiny vědy a techniky 11. 20. seminář pro vyučujici dějinám věd a techniky. Rozpravy NTM 182 (87-91). Praha: NTM.

Holton, G. (2003). What historians of science and science educators can do for one another. Science \& Education, 12(7), 603-616.

Dostupné z https://doi.org/10.1023/A:1025675922918

Horner, J. K. \& Rubba, P. (1978). The myth of the absolute truth. The Science Teacher, 45(1), 29-30.

Hyna, A. (2001). Dějiny vědy a techniky ve výuce učitele historie. In J. Folta (Ed.), Dějiny vědy a techniky 8. 17. a 18. seminář pro vyučujici dějinám věd a techniky. Rozpravy NTM 170 (97-105). Praha: NTM.

Jenkins, E. W. (2014). E. J. Holmyard and the historical approach to science teaching. In M. R. Matthews (Ed.), International handbook of research in history, philosophy and science teaching (2381-2432). Dordrecht: Springer. 
Jílek, T. \& Mach, P. (2002). K výuce dějin vědy a techniky na základních a středních školách. In J. Folta (Ed.), Dějiny vědy a techniky 9. 19. seminář pro vyučujíci dějinám věd a techniky. Rozpravy NTM 175 (63-64). Praha: NTM.

Karpenko, V. (1997). Výuka dějin chemie na vysokých školách. In J. Folta (Ed.), Dějiny vědy a techniky 3. Rozpravy NTM 145 (121-125). Praha: NTM.

Klopfer, L. E. \& Cooley, W. W. (1963). The history of science cases for high schools in the development of students' undestanding of science and scientists. Journal of Research in Science Teaching, 1(1), 33-47. Dostupné z https://doi.org/10.1002/tea.3660010112

Leite, L. (2002). History of science in science education: Development and validation of a checklist for analysing the historical content of science textbooks. Science \& Education, 11(4), 333-359. Dostupné z https://doi.org/10.1023/A:1016063432662

Lederman, N. G. (1992). Students' and teachers' conceptions of the nature of science: A review of the research. Journal of Research in Science Teaching, 29(4), 331-359. Dostupné z https://doi.org/10.1002/tea.3660290404

Matthews, M. R. (2011). Teaching the philosophical and worldview components of science - some considerations. In P. V. Kokkotas, K. S. Malamitsa \& A. A. Rizzaki (Eds.), Adapting historical knowledge production to the classroom (3-16). Rotterdam: Sense Publishers.

McComas, W.F. (2014a). History of science and the future of science education. A typology of approaches to history of science in science instruction. In P. V. Kokkotas, K. S. Malamitsa \& A. A. Rizzaki (Eds.), Adapting historical knowledge production to the classroom (37-55). Rotterdam: Sense Publishers.

McComas, W. F. (2014b). Nature of science in the science curriculum and in teacher education programs in the United States. In M. R. Matthews (Ed.), International handbook of research in history, philosophy and science teaching (1993-2023). Dordrecht: Springer.

Metz, D. (2014). The history and philosophy of science in science curricula and teacher education in Canada. In M. R. Matthews (Ed.), International Handbook of research in history, philosophy and science teaching (2025-2043). Dordrecht: Springer.

Monk, M. \& Osborne, J. (1997). Placing the history and philosophy of science on the curriculum: A model for the development of pedagogy. Science Education, 81(4), 405-424. Dostupné z https://doi.org/10.1002/(SICI)1098-237X(199707)81:4<405::AID$\mathrm{SCE} 3>3.0 . \mathrm{CO} ; 2-\mathrm{G}$

Potůček, J. (1998). Historie matematiky a školská matematika. In J. Folta (Ed.), Dějiny vědy a techniky 5. 15. a 16. seminář pro vyučujici dějinám věd a techniky. Rozpravy NTM 157 (59-65). Praha: NTM.

Poupová, J. (2018). Výuka o vědě a jejích dějinách: Česko versus Západ. Orbis scholae, 12(1), 1-17. Dostupné z https://doi.org/10.14712/23363177.2018.281

Rasmussen, C.S. (2007). The history of science as a tool to identify and confront pseudo-science. Journal of Chemical Education, 84(6), 949-951.

Dostupné z https://pubs.acs.org/doi/abs/10.1021/ed084p949

Rozhoň, V. (2002). Pár poznámek k problematice výuky dějin vědy a techniky na SS̆. In J. Folta (Ed.), Dějiny vědy a techniky 9. 19. seminář pro vyučujici dějinám věd a techniky. Rozpravy NTM 175 (65). Praha: NTM.

Rudge, D. W. \& Howe, E. M. (2009). An explicit and reflective approach to the use of history to promote understanding of the nature of science. Science $\& 3$ Education, 18(5), 561-580. Dostupné z https://doi.org/10.1007/s11191-007-9088-4 
Sjøberg, S. \& Schreiner, C. (2010). The ROSE project: An overview and key findings. Dostupné z http://roseproject.no/network/countries/norway/eng/nor-Sjoberg-Schreineroverview-2010.pdf

Strouhal, E. (1998). Poučení z dějin medicíny neuškodí. In J. Folta (Ed.), Dějiny vědy a techniky 5. 15. a 16. seminář pro vyučujici dějinám věd a techniky. Rozpravy NTM 157 (84). Praha: NTM.

Šindelář, J. (2001). Výuka dějin veterinární medicíny v ČR a v zahraničí. In J. Folta (Ed.), Dějiny vědy a techniky 8. 17. a 18. seminár̆ pro vyučujicí dějinám věd a techniky. Rozpravy NTM 170 (117-118). Praha: NTM.

Walker, R. (1993). Historical Science Experiments on File. New York: Fact on File, Inc.

Wang, H. A. \& Marsh, D. D. (2002). Science instruction with a humanistic twist: Teachers' perception and practice in using the history of science in their classrooms.

Science \& Education, 11(2), 169-189.

Dostupné z https://doi.org/10.1023/A:1014455918130

Wieder, W. (2006). Science as story communitating the nature of science through historical perspectives on science. American Biology Teacher, 68(4), 200-205.

Dostupné z https://doi.org/10.1662/0002-7685(2006)68[200:SASCTN]2.0.CO;2

JANA Poupová, jana.poupova@natur.cuni.cz

Univerzita Karlova, Př́rodovědecká fakulta

Katedra učitelství a didaktiky biologie

Viničná 7, Praha 2 - Nové Město, Česká republika 